Food, Dairy and Home Economic Research

http:/www.journals.zu.edu.eg/journalDisplay.aspx?Journalld=1\&queryType=Master

\title{
AZOLLA FERN AS UNTRADITIONAL RESOURCE OF PROTEIN
}

\author{
Mohamed A. Mohamed*, S.E. Elnemir, S.M. Abd El-Mounem and S.M. Abo El-Maati \\ Food Sci. Dept., Fac. Agric., Zagazig Univ., Egypt
}

Received: 19/02/2018 ; Accepted: 10/05/2018

\begin{abstract}
Azolla is a floating aquatic macrophyte belonging to the family of Azollaceae. The fern of azolla hosts a symbiotic ceyanobacteria (anabaena azollae), which is responsible for the fixation and assimilation of atmospheric nitrogen. Azolla has been reported to be a very good source of protein, essential mineral elements and vitamins. Out of several species, azolla (Azolla nolotica) has been reported to be best suited for tropical climate and livestock feeding. The measurements of colour, crude protein, crude fiber, ether extract, total ash and phenol compounds were recorded. In azolla, colour values of lightness (L) and yellow blue colours (b) were 39.15 and 7.38, respectively. On the other hand, the values of red to green colours (a) were 1.8. The mean concentration (\% of DM) of organic matter, crude protein, crude fibers, ether extract, total ash, nitrogen free extract (NFE) were $47.22,31.67,11.04,5.90,15$ and 36.39, respectively. Concentrated protein of azolla (ACP) could be used as feed supplement for human because its high levels of carbohydrate, protein, crude fat, total digestible nutrients and lower crude fiber contents. After concentration, the values of colours (lightness) decreased to 33.23. Also, the values of red to green colours (a) and yellow and blue colours (b) were decreased to 1.47 and 3.00, respectively after concentration. Chemical analysis indicated that (ACP) contained (DM \%) crude protein of 40.83, crude fiber (4.63), ether extract (5.06), ash (17) and carbohydrate (30.5). Added to that, the gross energy value of $434.67 \mathrm{kcal} / 100 \mathrm{~g}$ was obtained. The concentrations of calcium and phosphorus were 55.48 and $1.51 \%$, respectively.
\end{abstract}

Key words: Azolla, concentrated protein, nutritional, chemical evaluation.

\section{INTRODUCTION}

Azolla is a free floating aquatic fern belonging to family Azolaceae and can be easily propagated but requires abundant standing water, relative humidity of $85-90 \%$, $\mathrm{pH}$ of 4.5-6.5, salinity between 90 to $150 \mathrm{mg} / \mathrm{l}$ and adequate phosphorus for its nutritional needs. It is labour intensive, grows fast. Azolla doubles its weight in 3-5 days. It can reach a fresh weight of 15-20 t/ha in about 20 days (Shaltout et al., 2012).

Azolla is used as animal feed, human food and medicine, water purifier, green manure, hydrogen fuel, biogas producer, weed of insect controller, and reduces ammonia volatilization after chemical nitrogen application. It improves the water quality by removing excess quantity of nitrates and phosphorus (Costa et al., 2010).
More than 200 papers have been published on various aspects of azolla in relation to its nutritive value; its vitamin content nevertheless has so far received little attention despite its importance in animal nutrition. Azolla is a potential feed ingredient. Azolla is rich in protein; total protein is $(25-30 \%)$, so that it can be used as a plant protein source and provitamins for nutrition (Lejeune et al., 1999).

Azolla is rich in essential amino acids, vitamins, proteins, polyphenols, sugar, anthroquinone glycosides and steroids. The use of azolla as an ingredient in feed for poultry, broiler, hen and chickens (Alalade and Iyayi, 2006) has been tested, with favorable results. Due to the high productivity in natural conditions, nutritive value and fish appetency (Liu, 1988), azolla has been used as a potential ingredient in omnivorous and phytophagous fish feed (Abou et al., 2001). 
The aim of the present study is utilizing azolla fern to produce concentrated protein and evaluating its chemical and nutritional value in human food. The chemical attributes were evaluated before and after concentration.

\section{MATERIALS AND METHODS}

Fresh azolla; (Azolla nolotica) was obtained from Agricultural Research Center, Egypt and cultivated in pits under natural light and temperature 20 to $30^{\circ} \mathrm{C}$. Pits of size $8 \mathrm{ft} \times 5 \mathrm{ft}$ with depths of $10 \mathrm{~cm}$ were dug and spread with polyethylene sheets to hold the water. In each pit, $10-15 \mathrm{~kg}$ of sieved fertile soil was applied uniformly to a thickness of $3 \mathrm{~cm}$. Two kilograms of old cow dung was mixed with 10 1 of water and poured over it. Super phosphate was added along with cow dung slurry at a rate of $20-30 \mathrm{~g} / \mathrm{pit}$. Water was allowed to stand to a depth of $10 \mathrm{~cm}$ in the pit. About $10 \mathrm{~g}$ of super phosphate and $500 \mathrm{~g}$ of cow dung were added once every 4 days to fertilize the pits and to maintain the production rate of $1 \mathrm{~kg} /$ pit every day. Azolla multiplied rapidly and covered the complete pits within 7 days. Fully grown azolla was harvested every week from the water trough. The period of cultivation was 45 days.

\section{Methods of Processing}

\section{Processing of azolla concentrated protein}

Azolla concentrated protein was prepared according to the steps of Gouda $\boldsymbol{e t}$ al. (2015) and most of the process was run at low temperature to prevent protein destruction as follows:

\section{Washing process}

After collecting azolla, it must be first washed in $0.5 \%$ sodium bicarbonate solution and subsequently three times in tap water. Excess water was removed by screw press till the water content decreases to $83-84 \%$.

\section{Kneading process}

Solid salt $(\mathrm{NaCl})$ of $1-1.5 \%$ and solid sodium bicarbonate of $0.5-1.0 \%$ to the weight of azolla were added to cutted azolla and the mixture kneaded until it becomes a viscous past.

\section{Alcohol treatment process}

The azolla paste was extruded and the first ethanol treatment was done. The temperature of the ethanol should be about $5^{\circ} \mathrm{C}$. After the first ethanol treatment, the paste was passed through an extruder and put into the second ethanol treatment. The purpose of the second ethanol treatment was to bleak the hard coating of the surface caused denaturation in the first ethanol treatment.

\section{Drying}

The half-finished product had 50\% ethanol. The ethanol was removed by centrifugation and the half finished product was transferred to the drying process. A drier at $70^{\circ} \mathrm{C}$ hot air blows away the remaining ethanol into the circulating air and dried the product.

\section{Method of Analyses}

\section{Physical analyses}

Weight was observed by a digital scale with five grams graduation. Protein yield was calculated as obtained concentrated protein/100 grams of dry sample $\times 100$ (Omar, 1998).

Viscosity was determined using a Brookfield Viscometer (Model DV-I, USA) at room temperature $\left(25 \pm 1^{\circ} \mathrm{C}\right)$ with spindle No.2 at speed of $60 \mathrm{rpm}$ as described by Askar and Treptow (1993).

The $\mathrm{pH}$ was measured using a digital $\mathrm{pH}$ meter (Model 41150 S/N 790aa $411 \mathrm{Icm} 163$ S.W) at $25^{\circ} \mathrm{C}$ (AOAC, 2000).

Colour was measured colormetric using tristimulus colour machine with the CIE lab colour scale (Hunter, Lab Scan XE- Reston VA, USA) whereas; $\mathrm{L}=$ white (100) to black (-80), $\mathrm{a}=$ red (100) to green $(-80)$ and $b=$ yellow (70) to blue (-80). Three values of (L), (a) and (b) were taken. Results were expressed as lightness (L), Chroma $(C)=\left[(a)^{2}+(b)^{2}\right]^{1 / 2}$, hue angle (hab $=$ tan${ }^{1}$ [(b) (a)-1] , where $0^{\circ}=$ red purple; $90^{\circ}=$ yellow; $180^{\circ}=$ bullish green; $270^{\circ}=$ blue. Euclidean distance between two colours points $(\Delta \mathrm{E})$ was calculated as the mean square of differences in individual (L), (a) and (b) values $\left[\Delta \mathrm{E} .=\left(\Delta \mathrm{L}^{2}+\right.\right.$ $\left.\left.\Delta \mathrm{a}^{2}+\Delta \mathrm{b}^{2}=\right)\right]_{1 / 2}^{1 / 2}$ (Sapers and Douglas, 1987).

Energy content was calculated according to the equations of Gross energy (GE) $\left(\mathrm{Kcal} \mathrm{Kg}^{-1}\right)=$ 
$5.72 \mathrm{CP}(\%)+9.5 \mathrm{EE}(\%)+4.79 \mathrm{CF}(\%)+$ 4.03 NFE (\%) (NRS, 1984), Digestible crude protein $(\mathrm{DCP})($ in DW \%) $=0.929 \mathrm{CP}($ in $(\%)$ DW) - 3.52 (Demarquilly and Weiss, 1970), total digestible nutrients $(\mathrm{TDN})($ in $(\%) \mathrm{DW})=$ $0.623(100+1.25 \mathrm{EE})-0.72 \mathrm{P}$ (Naga and ElShazly, 1971), Digestible energy (DE) (Mcal $\left.\mathrm{kg}^{-1}\right)=0.0504 \mathrm{CP}(\%)+0.077 \mathrm{EE}(\%)+0.02$ $\mathrm{CF}(\%)+0.000377(\mathrm{NFE})^{2}(\%)+0.011(\mathrm{NFE})$ $(\%)-0.152 \times 1000$ (NRS, 1984), Metabolized energy $(\mathrm{ME})=0.82 \mathrm{DE}$ (Garrett, 1980) and Net energy $(\mathrm{NE})=0.50 \mathrm{ME}$ (NRS, 1984); whereas $\mathrm{EE}=$ Ether extract, $\mathrm{CF}=$ Crude fiber, $\mathrm{CP}=$ Crude protein and NFE $=$ Nitrogen free extract

\section{Determination of protein solubility}

One gram of product powder was added to $40 \mathrm{ml}$ of distilled water and $3 \% \mathrm{NaCl}$. A vortex mixer (Thermolyne Maxi Mix II, USA) was used for $2 \mathrm{~min}$ to homogenize the samples. Aliquots were centrifuged (Hettich Universal $30 \mathrm{RF}$ ) at $6280 \mathrm{rpm} / 5 \mathrm{~min}$ and the supernatants were collected for protein estimation. The protein solubility was calculated on the basis of $100 \%$ solubility of the protein (Venugopal and Shahidi, 1996).

\section{Determination of water and oil holding capacities}

The method of Yasumatsu et al. (1972) was followed to determine the water and oil holding capacities. The sample was mixed with water or corn oil (1: 10) and mixed for $30 \mathrm{sec}$ using a Moulinex mixer (Type 716, France) at the maximum speed. The samples were then allowed to stand at room temperature for 30 min and centrifuged at $5000 \mathrm{rpm}$ for $30 \mathrm{~min}$. The volume of supernatant was recorded in a $10 \mathrm{ml}$ graduated cylinder. Results were expressed on dry weight basis.

\section{Determination of emulsifying capacity}

Five grams of product powder was added to $25 \mathrm{ml}$ of distilled water and $25 \mathrm{ml}$ of corn oil. The mixture was then blended (Waring Blender, USA) for $1 \mathrm{~min}$ and transferred to a $50 \mathrm{ml}$ calibrated centrifuge tube. The tube was centrifuged at $7500 \mathrm{rpm}$ for $5 \mathrm{~min}$ (Hettich Universal $30 \mathrm{RF}$, USA). The emulsification was calculated by dividing the emulsion volume after centrifugation by the original emulsion volume and then multiplying by 100 (Yasumatsu et al., 1972).

\section{Whippability and foaming stability}

Three grams of product powder were dispersed in $100 \mathrm{ml}$ of distilled water and the mixture was homogenized for 1 min using a Polytron homogenizer at setting 4 . The mixture was then poured into a $250 \mathrm{ml}$ graduated cylinder and the total volume was read. Whippability was expressed as percentage volume increase upon whipping, and foaming stability was calculated as the volume of foam remaining after $0,5,10,40$ and $60 \mathrm{~min}$ quiescent periods (Sathe and Salunkhe, 1981).

\section{Turbidity}

Samples of azolla product powder were diluted with distilled water ratio of 1:100. The absorbance of the dispersions was determined at $600 \mathrm{~nm}$ on a UV-Vis spectrophotometer. This absorbance was used as an indicator of turbidity (Xu et al., 1996).

\section{Gravimetric analysis}

Gravimetric analysis of the coagulum or the supernatant after centrifugation has been employed due to the method of the coagulation process. Recovering or separating the precipitate or coagulum from the solution can be difficult because the precipitates can vary from rapidly sedimenting flocculates to non sedimenting, sollike opaque aggregates. To follow thermal precipitation of protein solutions, Hegg et al. (1978) removed volumes of solution at various time or temperature intervals of heating, centrifuged the solution, and calculated the percentage of aggregated protein as the decrease in absorbance of the supernatants at $380 \mathrm{~mm}$. For slower-sedimenting plateaus, absorbance at 340 $\mathrm{nm}$ (opalescence) of the supernatants was measured.

\section{Cooking yield}

Twenty grams of sample with or without added hydrolysate, were transferred into a preweighed 5\% centrifuge tube and homogenized with 20 grams of water. Tubes were covered with aluminum foil and placed in a boiling water bath for $20 \mathrm{~min}$. The mixture was then cooled to room temperature and centrifuged for $15 \mathrm{~min}$ at 3000 rpm. The juice released was decanted and the sample was blotted over a Whatman No. 1 filter 
paper and transferred back into the tube. The percent of cooking yield was calculated from the weight difference data (Shahidi et al., 1994).

\section{Chemical analyses}

Moisture content, ash, fat ether extract, minerals (calcium and phosphorus), carbohydrates and crude fiber contents were determined according to AOAC (2000).

Total nitrogen content was determined by kjeldahl method and crude protein content of the fresh samples was measured by multiplying the nitrogen value by 6.25 (Femenia et al., 2008).

Total phenolic substances were measured calorimetrically (as tannic acid) at $640 \mathrm{~nm}$. Samples were extracted in alcohol $95 \%$, centrifuged and Foline-Ciocalteu reagent was used as indicator (Dóka and Bicanic, 2002).

\section{RESULTS AND DISCUSSION}

The yield of azolla was reported of about $100 \mathrm{~g} / \mathrm{m}^{2} /$ day of fresh weight per water trough. The production of aquatic plants is regulated by climatic and environmental factors such as temperature, day length, solar irradiance, and length of growing season, humidity, nutrients, salinity and $\mathrm{pH}$ (Eid et al., 2012).

In azolla, the dry weight calculated was $8.1 \%$ of fresh weight. Parashuramulu and Nagalakshmi (2013) reported the value of $8.9 \%$. The results of proximate chemical composition of dried azolla are presented in Table 1. The results of dried azolla were 3-5\% moisture, $31.67 \%$ crude protein, $5.9 \%$ fat (ether extract), $11.04 \%$ of crude fiber, $15 \%$ total ash, $34.5 \%$ carbohydrate and $36.39 \%$ nitrogen free extract. On the other hand, azolla protein concentrated (APC) had the values of $3 \%$ moisture, $40.83 \%$ crude protein, $5.06 \%$ fat (ether extract), $17 \%$ ash, $4.63 \%$ crude fiber and $30.5 \%$ carbohydrate. These results are in accordance with those obtained by Moore (1969). On the other hand, dry matter content was $9.73 \%$ (Cherryl et al., 2014) which was in close agreement with the results of Balaji $\boldsymbol{e t} \boldsymbol{a l}$. (2009).
The crude protein content of azolla and ACP estimated in the study was 31.67 and $40.83 \%$, respectively (Table 1), which indicated that azolla could be used as a potential natural protein source in feeding humans. The crude protein value estimated is almost similar to the results obtained by Kumar et al. (2012). The high protein content could be due to high nitrogen content fixed by the endosymbiotic nitrogen fixing bacterium, Anabaena azollae (Pillai et al., 2002).

On dry matter basis, azolla and ACP content of fat (ether extract) was at level of 5.90 and $5.06 \%$, respectively (Table 1). Similar result of 66.7\% was obtained by Shiomi and Kitoh (1987). Generally, ether extract values varied between 1.60 and $5.05 \%$. The results are near with findings of other researchers (Basak et al., 2002). Drying conditions did not significantly affect lipid composition or yields, indicating that drying conditions may be energetically optimized without the risk of product loss.

In azolla and ACP, the ash content was 15 and $17 \%$, respectively (Table 1 ). The total ash content of azolla obtained in the present study was lower than the values reported by Ali and Leeson (1995) but higher than the value reported by Singh and Subudhi (1978).

For crude fiber, the values of 11.04 and $4.63 \%$ were recorded in azolla and ACP, respectively (Table 1). The higher values of crude fiber were recorded by Kavya (2014) (15.15\%), while low crude fiber content of 9.2-11.3\% was recorded by Shiomi and Kitoh (1987). In azolla powder and APC, the values of carbohydrates were 34.5 and $30.5 \%$, respectively (Table 1). Total carbohydrates in Azolla filiculoides are less than Trifolium alexandrinum (43.4\%) (Chauhan et al., 1980).

Phenolic contents were higher than $1.9 \%$ (Table 1). No work has so far been reported on the optimization of extraction of bioactive compounds from them.

In azolla and ACP, the values of nitrogen free extract (NFE) were higher of about 36.39 and 32.48 (Table 1). These values are the nearest to whose recorded by Cherryl et al. (2014) (33.84\%), Chatterjee et al. (2013) (37.71\%), Alalade and Iyayi (2006) (47\%).

For organic carbon, the values of azolla and ACP were 47.22 and 46.11, respectively (Table 1). 
Table 1. Chemical properties of azolla, and azolla concentrated protein (ACP)

\begin{tabular}{lcc}
\hline Component (\%) & \multicolumn{2}{c}{ Values* } \\
\cline { 2 - 3 } & Azolla & Azolla protein concentration \\
& (Azolla nolotica) & (ACP) \\
\hline Moisture & $3-5$ & 3.0 \\
Crude protein & 31.67 & 40.83 \\
Ether extract & 5.90 & 5.06 \\
Ash & 15 & 17 \\
Crude fiber & 11.04 & 4.63 \\
Carbohydrate & 34.5 & 30.5 \\
Phenols & 1.98 & 1.95 \\
Nitrogen free extract** & 36.39 & 32.48 \\
Organic carbon $(\mathbf{C}) * * *$ & 47.22 & 46.11 \\
pH & 7.95 & 7.70 \\
Ca & 47.20 & 55.48 \\
P & 8.92 & 1.51 \\
\hline
\end{tabular}

* Values are means of three determinations and based on $100 \mathrm{~g}$ of dry weight.

$* *$ Nitrogen free extract $=(100-$ crude protein + lipid + ash+crude fiber $)$.

*** Formula; percentage carbon $=(100-$ percentage ash $) / 1.8$. (Golueke, 1977).

Bolka (2011) reported 70-80\% of organic matter, while Chatterjee et al. (2013) showed a value of $80.53 \%$. Kavya (2014) showed a value of $82.16 \%$. Also, Shiomi and Kitoh (1987) recorded a value between 35.1 to $46.2 \%$.

The percentages of calcium and phosphorus in azolla were 47.20 and $8.92 \%$ while in ACP calcium increased to $55.48 \%$, while phosphorous content decreased to $1.51 \%$ (Table 1). The calcium level of azolla obtained in this study was close to the reported value of Alalade and Iyayi (2006) but lower than that reported by Cherryl et al. (2014) who indicated that Azolla microphylla contained $2.58 \%$. Balaji et al. (2009) found $0.4 \%$ and $0.44 \%$ phosphorus in azolla.

From Table 2, as $\mathrm{Kcal} / \mathrm{Kg}$ of dry weight (DW), the energy content of azolla and ACP was recorded. Azolla has high content of gross energy (GE) of 436.73 and this value decreased to 434.67 after concentration the protein of azolla. This may be due to the loss in components during concentration process.

On the other hand, the digestible crude protein (DCP) was increased from 259 in azolla powder to 344.1. This may be due to high content of protein in ACP. Contrary, total digestible nutrients (TDN) were 440.9 in azolla powder and decreased to 368.5 in ACP.

Generally, the net energy can be obtained from consuming azolla or ACP was in the same range of 123 and $127 \mathrm{Mcal} / 100 \mathrm{~g}$ of dry weight, despite the wide difference in chemical composition between azolla powder and ACP.

As for azolla powder (Table 2), lightness (L) value was 39.15. After concentration, the value decreased to 33.23. The lightness value of ACP was less than obtained for Cat fish concentrate (73.8) (Kristinsson et al., 2005). Changes in lightness (L) were attributed to browning on the surface and loss of water indicating that tissues became darker with storage period (Rattanaponone et al., 2001). 
In azolla powder, the value of (a) parameter which reflects losses of red and green colour recorded 1.80. For concentrated protein of azolla (ACP) the value decreased to 1.47 after concentration process.

Concerning losses of yellow and blue colours (b) (Table 2), there were changes in (b) values. For azolla powder, the value was 7.38 and decreased to 3.00 in azolla protein concentrated (ACP).

According to Ahmed et al. (2002), the changes in (a) and (b) values are associated with a simultaneous change in the value of lightness (L). Generally, high content of dry matter (soluble solids) had high chroma value (Amaro et al., 2012).

After concentration, there were an effect on colour was observed due to changing in hue angle values from $76.29^{\circ}$ for azolla and powder to $63.88^{\circ}$ in concentrated protein of azolla (ACP). Hue angle $\left({ }^{\circ} \mathrm{Hue}\right)$ may improve the understanding of colour variations (Fonteles et al., 2012).

The decrease or increase in hue angle values may be due to clear relationship between hue angle, lightness (L) and red to green colours (a) values. In this respect, Solvat et al. (2012) showed that storage temperature had an effect on hue angle values.

Total colour difference values $(\Delta \mathrm{E})$ were 39.88 for azolla powder, and then decreased to 33.39 in concentrated protein of azolla (ACP).

Choi et al. (2002) suggested that the values of total colour difference $(\Delta \mathrm{E})$ which more than 2 corresponds to visually perceptible difference in various products. Thus, the colour of ACP did not show visual difference compared to untreated samples. These results are positive.

In Table 3, results showed the changes in protein solubility of azolla protein concentrate (ACP) during storage at room temperature. Also, they showed that protein solubility of ACP was high at $\mathrm{pH} 12$ of $699 \%$. The changes in solubility proteins under a variety of extracting conditions has been taken as a measure of change in protein conformation i.e., denaturation, and has been used as an indicator of the quality change that undergone. In addition, many functional properties of muscle food protein have been related to the solubilization of the protein in salt solution.

On contrary, the changes in emulsifying capacity of ACP during storage at room temperature were high at low $\mathrm{pH} 4$ of $74 \mathrm{~g}$ oil $/ \mathrm{g}$ protein and decreased to $64 \mathrm{~g}$ oil/g protein at $\mathrm{pH}$ 12 (Table 3). Hermansson (1971) reported that the protein concentrate can also produced at temperature of $50^{\circ} \mathrm{C}$ but it will have lower emulsifying properties and poor solubility.

On the other hand, the values of turbidity were different. At $\mathrm{pH} 4$, the turbidity value was 1.298 and decreased to 0.315 at $\mathrm{pH}$ of 7-7.2 and 0.352 at $\mathrm{pH} 12$ (Table 3). Shimada and Matsushita (1980) found that the turbidity of a $4.5 \%$ protein solution (3.6\% ovalbumin, $0.9 \%$ conalbumin) heated for $15 \mathrm{~min}$ at $80^{\circ} \mathrm{C}$ decreases as the $\mathrm{pH}$ increases from 8 to 11 , after which no turbidity was observed.

In Table 3, the results show the changes in water holding capacity of ACP at room temperature. The results showed that, water holding capacity was higher $(420 \%)$ at $\mathrm{pH}(7-7.2)$ and decreased to $380 \%$ and $300 \%$ at $\mathrm{pH} 4,12$, respectively. These results are similar to that found by Ogunlade et al. (2005), since who stated that the water holding capacity of the fish products are generally in the range of 280-404\%.

Abou-Zaid and Elbandy (2014) showed that protein extraction process caused the increase in the water holding capacity (WHC) value for azolla protein concentrate powder. Also, the most porous structure was formed during extraction as a result of removing some fatty matters and forming hydrogen bonds during the milling it may be the reason for more entrained water.

\section{OD Optical density}

However, the percentage of whippability was high at $\mathrm{pH} 4$ and $\mathrm{pH} 7-7.2$ of about $103.33 \%$ and decreased to $96.66 \%$ at $\mathrm{pH} 12$. In this respect, Zhang et al. (2010) showed that enzymatic treatment increased foam volume/ height but decreased foam stability. The trend of increased foam volume being coupled with decreased foam stability has been reported in previous studies on rice bran protein. Added to that, the foam stability recorded a decrease during one hour, under the different values of $\mathrm{pH}$ values of 4,7 and 12 and 
Zagazig J. Agric. Res., Vol. 45 No. (4) 2018

Table 2. Energy and colour parameters of azolla and azolla concentrated protein (ACP)

\begin{tabular}{lcc}
\hline Parameter & $\begin{array}{c}\text { Azolla } \\
\text { (Azolla nolotica) }\end{array}$ & $\begin{array}{c}\text { Azolla protein concentration } \\
\text { (ACP) }\end{array}$ \\
\hline Energy content & 436.73 & 434.67 \\
Gross energy (GE) & 259 & 344.1 \\
Digestible crude protein (DCP) & 440.9 & 368.5 \\
Total digestible nutrients (TDN) & 300 & 310 \\
Digestible energy (DE) & 246 & 254 \\
Metabolized energy $(\mathbf{M E})$ & 123 & 127 \\
Net energy $(\mathbf{N E})$ & & \\
Colour Parameters & 39.15 & 33.23 \\
Lightness $(\mathbf{L})$ & 1.80 & 1.47 \\
Red and green colours $(\mathbf{a})$ & 7.38 & 3.00 \\
Yellow and blue colours $(\mathbf{b})$ & $7.59^{-15}$ & 3.34 \\
Chroma $(\mathbf{C})$ & $76.29^{\circ}$ & $63.88^{\circ}$ \\
Hue angle & 39.88 & 33.39 \\
Total colour difference $(\Delta \mathbf{E})$ & &
\end{tabular}

Table 3. Some functional properties of azolla concentrated protein (ACP) at room temperature $\left(25^{\circ} \mathrm{C}\right)$

\begin{tabular}{|c|c|c|c|}
\hline \multirow[t]{2}{*}{$\overline{\text { Property }}$} & \multicolumn{3}{|c|}{ pH } \\
\hline & 4 & $7-7.2$ & 12 \\
\hline$\overline{\text { Solubility (\%) }}$ & 598 & 559.4 & 699 \\
\hline Emulsifing (g/g protein) & 74 & 70 & 64 \\
\hline Turbidity (O.D.) & 1.298 & 0.315 & 0.352 \\
\hline Water holding capacity (\%) & 380 & 420 & 300 \\
\hline Oil holding capacity (\%) & 710 & - & - \\
\hline Whippability (\%) & 103.33 & 103.29 & 96.66 \\
\hline \multicolumn{4}{|l|}{ Foam stability (\%) } \\
\hline $0-5 \min$ & 90 & 100 & 86.63 \\
\hline $10 \mathrm{~min}$ & 86.66 & 96.65 & 83.33 \\
\hline $40 \mathrm{~min}$ & 86.60 & 96.65 & 80 \\
\hline $60 \mathrm{~min}$ & 80 & 96.60 & 80 \\
\hline Viscosity (m.Pascal $\left./ 25^{\circ} \mathrm{C}\right)$ & 0.325 & 0.452 & 0.25 \\
\hline Cooking yield (\%) & 88.33 & 93.33 & 91.66 \\
\hline Gravimetric analysis (OD) & 1.087 & 0.738 & 1.160 \\
\hline
\end{tabular}


reached to $80 \%$, except the high stability of 96.6 at $\mathrm{pH}$ 7-7.2. The absence of large protein components, which function to stabilize the foam, may contribute to the observed lack of foam stability (Claver and Zhou, 2005). Regarding the effect of $\mathrm{pH}$ on foaming, barley proteins had greater foam stability at basic $\mathrm{pH}$ values and very low stability at acidic $\mathrm{pH}$ (Harper et al., 1992).

At $\mathrm{pH}$ 7-7.2, the viscosity index recorded $0.452 \mathrm{~m}$. Pascal. This value decreased to 0.325 and 0.25 at $\mathrm{pH}$ of 4 and 12 , respectively. Up to $80 \mathrm{~min}$ of heating, the decreases in viscosity index were observed. As an indicator for aggregation of protein, gravimetric analyses was low at $\mathrm{pH}$ 7-7.2 of about 0.73 and increased to 1.087 and 1.16 at $\mathrm{pH} 4$ and 12, respectively. These results are in acceptance with those obtained by Nakamura et al. (1978) whom concluded that the main factor contributing to the heat induced aggregation of protein (pI 4.54.6) is the degree of electrostatic repulsion among the denatured protein molecules.

\section{REFERENCES}

Abou, Z.A., F.F. Mohamed and M.S.M. Radwan (2001). Assessment of the nutritive value of dried azolla hay as a possible feed ingredient for growing NZW rabbits. Egyptian J. Rabbit Sci., 11(1): 1-21.

Abou-Zaid, A.A.M. and M.A.S. Elbandy (2014). Production and quality evalution of nutritions high quality biscuits and potato puree tablets supplemented with crayfish (Procombbarus Clarikia). Prot. J. Appl. Sci. Res., 1-8.

Ahmed, J., U.S. Shirhara and M. Kaur (2002). Thermal colour degradation kinetics of mango puree. Int. J. Food Prop., (5): 359-366.

Alalade, O.A. and E.A. Iyayi (2006). The nutritive value of azolla (Azolla pinnata) meal in diets for growing pullets and subsequent effect on laying performance. J. Poult. Sci., 44 : 273-277.

Ali, M.A. and S. Leeson (1995). Nutritional value and aquatic weeds in the diet of poultry. World's Poult. Sci. J., 50: 239-251.

Amaro, L.A., J.C. Beaulieu, C.C. Grimm and E.R. Stein (2012). Effect of oxygen on aroma volatiles and quality of fresh-cut cantaloupe and honeydew melons. J. Food Chem., (130): 49- 57.

AOAC (2000). Official Methods of Analysis of AOAC. Int. $17^{\text {th }}$ Ed. Gaithersburg, Maryland, USA.

Askar, A. and H. Treptow (1993). Quality Assurance in Tropical Fruit Prescessing. Springer Verlag, Berlin, Germany, 57-60.

Balaji, K., A. Jalaludeen, R.R. Churchil, P.A. Peethambaran and S. Senthilkumar (2009). Effect of dietary inclusion of Azolla (Azolla pinnata) on production performance of broiler chicken. IJPS, 44 (2): 195-198.

Basak, B., A.H. Pramanik, M.S. Rahaman, Taraf dar Su and B.C. Roy (2002). Azolla (Azolla pinnata) as a feed ingredient in broiler ration. Int. J. Poult. Sci., 1 : 29-32.

Bolka, P.C. (2011). Nutritional evaluation of azolla (Azolla pinnata) in broilers and layers. Ph.D. Thesis Sub. to Karnataka Vet., Anim. and Fish. Sci. Univ., Bidar.

Chatterjee, A., P. Sharma, M.K. Ghosh, M. Mandal and P.K. Roy (2013). Utilization of Azolla microphylla as feed supplement for crossbred cattle Int. J. Agric. and Food Sci. Tech., 4 : 207-214.

Chauhan, T.R., R.S. Gills and J.S. Ichhponani (1980). Nutritive value of berseem and clusterbean forages. Indian J. Anim. Sci., 50: 1052-1055.

Cherryl, D.M., R.M.V. Prasad, S. Jagadeeswararao, P. Jayalaxmi and D.S. Kumar (2014) A study on the nutritive value of Azolla pinnata. Livest. Res. Int., 2: 13-15.

Choi, M.H., G.H. Kim and H.S. Lee (2002). Effect of ascorbic acid retention on juice colour and pigment stability in blood orange (Citrus senensis) juice during refrigerated storage. Food Res., Int., 35: 753-759.

Claver, I.P. and H. Zhou (2005). Enzymatic hydrolysis of defatted wheat germ by proteases and the effect on the functional properties of resulting protein hydrolysates. J. Food Biochem., 29 : 18-25.

Costa, M.L., M.C.R. Santos and F. Carrapico (2010). Potential uses of Azolla filiculoides 
biomass grown in natural ecosystems and urban waste water. Proc. $14^{\text {th }}$ Ramiran Int. Conf., Lisboan.

Demarquilly, C. and P. Weiss (1970). Tableau de la valeur alimentaire des fourrages. Versailles INRA-SEI, Paris.

Dóka, O. and D. Bicanic (2002). Determination of total polyphenolic content in red wins by means of the Folin-Ciocalteu colourimetry assay. Anal. Chem., (74): 2157-2161.

Eid, E.M., K.H. Shaltout and T. Asaeda (2012). Modeling growth dynamics of Typha domingensis (Pers.) Poir. ex Steud. in Lake Burullus, Egypt. Ecol. Model., 243: 63-72.

Femenia, A., G.S. Serrano, S. Simal and M.C. Garau (2008). Effects of air drying temperature on the cell walls of kiwifruits processed at different stage of ripening. Chem. Dept., Universitate de les Illes balears. Ctra Valldemossa Km 7.5.07071 Palmade Mallorca, Spain.

Fonteles, V.Y., M.G.M. Costa, T.D. Jesus, L.A.R.M. Alcantara de Miranda, N.A.F. Fernandes and S. Rodrigues (2012). Power ultrasound processing of cantaloupe melon juice: Effects on quality parameters. Food Res. Int., (48): 41-48.

Garrett, W.N. (1980). Energy Utilization of Growing Cattle as Determined in Seventytwo Comparative Slaughter Experiments. In: LE Mount (ed.), Energy metabolism. Butterworths, London.

Golueke, C.G. (1977) Biological reclamation of solid wastes. Rochdalepress. Pennsylvania, 24.

Gouda, N.S.E., S.S. Bassuiny, A.M. Sulieman and G.F. Mohamed (2015). Chemical and technological studies on some fish. M.Sc., Fac. Agric., Zagazig Univ., Egypt.

Harper, W., R. Boer, P. Jelen and Z. Puhan (1992). Functional properties of whey protein concentrates and their relationship to ultrafiltration. In: New Applications of Membrane Processes, Int. Dairy Federation Special Issue 9201; Int. Dairy Federation: Brussels, Belgium, 77-108.
Hegg, P.O., H. Martens and B. Lofqvist (1978). Effects of $\mathrm{pH}$ and neutral salts on the formation and quality of thermal aggregates of ovalbumin. A study on thermal aggregation and denaturation. J. Sci. Food Agric., 30: 981.

Hermansson, A.M. (1971). Aggregation and Denaturation Involved in Gel Formation. In: Functionality and Protein Structure, A. PourEl, Ed., ACS Symp. Series 92, 81. Ame. Chem. Soc., Washington, DC.

Kavya, K. (2014). Nuritional evaluation of Azolla (Azolla pinnata) and its supplementary effect on in vitro digestibility of crop residues and total mixed ration. M.Sc. Thesis Submitted to Karnataka Vet., Anim. and Fish. Sci. Univ., Bidar. India.

Kristinsson, H.G., A.E. Theodore, N. Demir and B. Ingadottir (2005). Acomparative study between acid and alkali- added processing and surimi processing for the recovery of proteins from channel catfish muscle. J. Food Sci., 70 : 298-306.

Kumar, D.S., R.M.V. Prasad, K.R. Kishore and E.R. Rao (2012). Effect of Azolla (Azolla pinnata) based concentrate mixture on nutrient utilization in buffalo bulls. Ind. J. Anim. Res., 46: 268-271.

Lejeune, A., A. Cagauan and C. Van Hove (1999). Azolla research and development: recent trends and priorities. Symbiosis, in press Costa.

Liu, C.C. (1988). The Rice-Azolla-Fish system. RAPA Bulletin, FAO, Bangkok, 4: 37.

Moore, A.W. (1969). Azolla: biology and agronomic significance. Bot. Rev., 35:17-34.

Naga, M.A. and K. El-Shazly (1971). The prediction of the nutritive value of animal feeds from chemical analysis. J. Agric. Sci., 77: $25-31$.

Nakamura, R., H. Sugiyama and Y. Sato (1978). Factors contributing to heat-induced aggregation of ovalbumin. Agric. Biol. Chem., 42: 819.

NRS/Nutrient Requirements of Sheep (1984). National Research Council National Academy Press Washingtom D.C. 
Ogunlade, I., O. Olaofe and T. Fedare (2005). Chemical composition, amino acids and functional properties of selected seafoods. J. Food Agric., Environ., 3 : 130.

Omar, A.M. (1998). Technological studies on fruit juice concentrate. Ph.D. Thesis, Fac. Agric., Zagazig Univ., Egypt.

Parashuramulu, P.S. and D. Nagalakshmi (2013). Protein fractionation and in vitro digestibility of azolla in ruminants. J. Anim. Feed Res., 3 (3): 129-132.

Pillai, K.P., S. Premalatha and S.R. Mony (2002). Azolla a sustainable feed substitute for livestock. Leisa India, 4 : 15-17.

Rattanaponone, N., Y. Lee and A.F. Watada (2001). Quality and microbial changes of fresh-cut mango cubes held in controlled atmosphere. Hort. Sci., 36 : 1019-1050.

Sapers, G. and F. Douglas (1987). Measurement of enzymatic browning at cut surfaces and in juice of raw apple and pear fruits. J. Food Sci., $52:$ 1258-1262.

Sathe, S.K. and D.K. Salunkhe (1981). Function properties of the great northern bean (Phaseolus vulgaris) proteins. Emulsion, foaming, viscosity and gelation properties. J. Food Sci., 64:71-75.

Shahidi, F., X. Qinghan and J. Synowiecki (1994). Production and characteristics of protein hydrolysates from capelin (Mallotus villosus). Food Chem., 53: 193-285.

Shaltout, K.H., T.M. El-Komi and M.E. Ebrahem (2012). Seasonal variation in the phytomass, chemical composition and nutritional value of Azolla filiculoides Lam. Along the water courses in the Nile Delta, Egypt. Feedes Repertorium, $1: 37-49$.

Shiomi, N. and S. Kitoh (1987). Use of Azolla as a decontaminant in sewage treatment. In Azolla Utilization, Ed. W.H. Smith, Int. Rice Res. Inst., Los Banos., 169-176.

Shimada, K. and S. Matsushita (1980). Thermal coagulation of egg albumin. J. Agric. Food Chem., $28: 409$.

Singh, P.K. and B.P.R. Subudhi (1978). Utilization of azolla in poultry feed. Indian Farm., 27: 37-39.

Solvat, M.K., S. Sundararajan, L. Alfar and S. Sathivel (2012). Development of cantaloupe (Cucumis melo) juice powder using spray drying technology. Food Sci., Technol., (46): 287-294.

Venugopal, V. and F. Shahidi (1996). Thermostable water dispersions of myofibrillar proteins from Atlantic mackerel (Scomber scambrus). J. Food Sci., 59: 265-276.

Xu, S., J.H. Harrison and R.E. Riley (1996). Characteristics of nitrogen fractions and amino acids of feedstuffs common to the Pacific Northwest. Prof. Anim. Sci., 12: 223237.

Yasumatsu, K., K. Sawada, S. Moritakea, M. Misaki, J. Todo, T. Wada and K. Ishil (1972). Whipping and emulsifying properties of soybean products. Agric. Biol. Chem., 36 : 719.

Zhang, H.J., H. Zhang, L. Wang and X.N. Guo (2010). Preparation and functional properties of rice bran proteins from heat stabilised defatted rice bran. Food Res. Int., 47: 359363. 


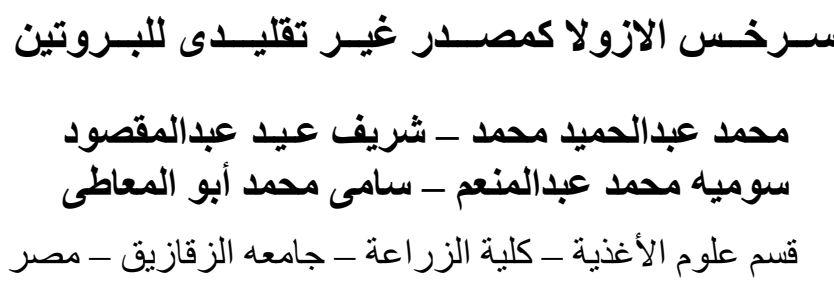

تعتبر الازولا من النباتات الطافية على سطح الماء و التي تنتمي إلى عائلة Azollaceae وهذاء وهذا النبات الطافي يعول

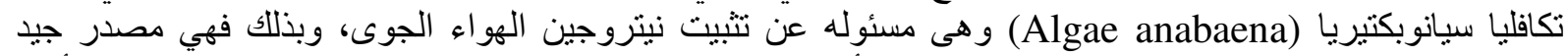

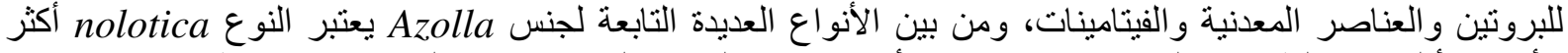

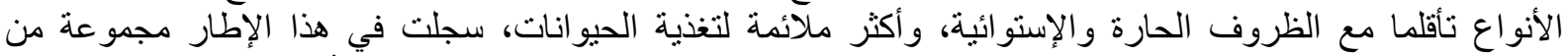

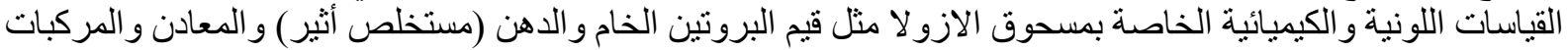

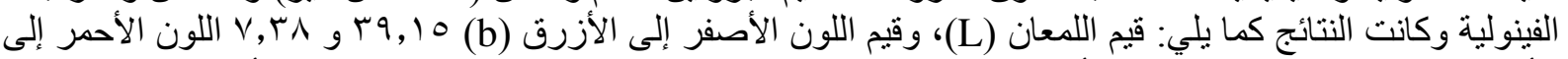

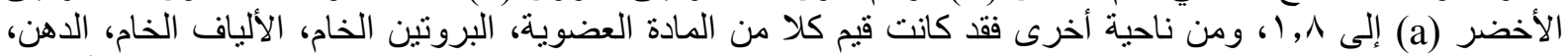

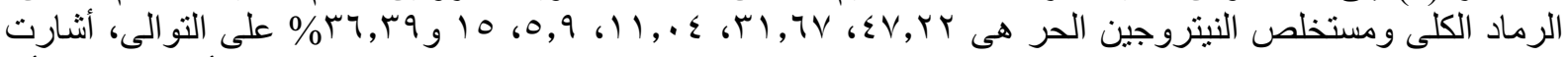

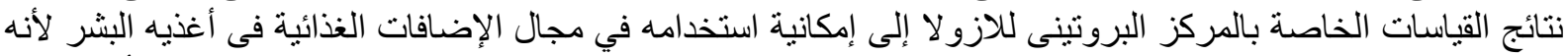

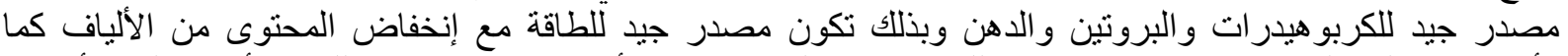

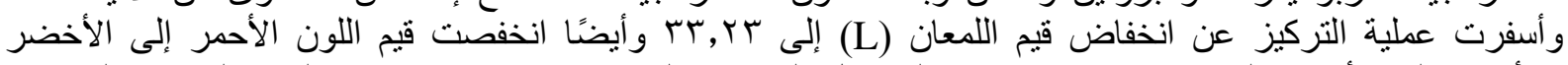

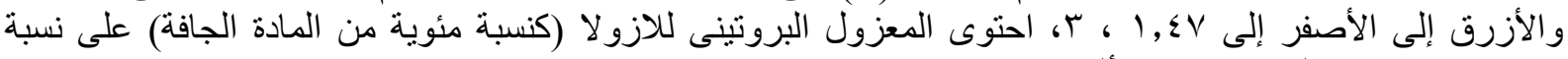

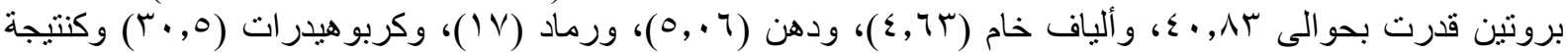

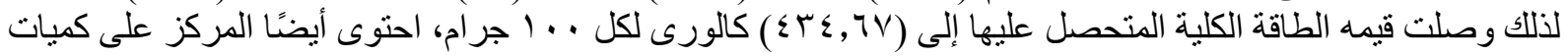

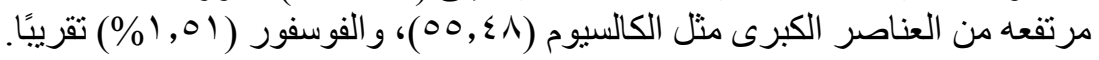

